\title{
Ileocolic intussusception and hydrostatic reduction in a 2-year-old girl
}

\author{
Jan Menke \\ Department of Diagnostic Radiology, University Hospital Goettingen, Goettingen, Germany
}

Correspondence to Dr Jan Menke, Menke-J@T-Online.de

\section{DESCRIPTION}

A 2-year-old previously well girl presented at the hospital with intermittent acute painful crying (colicky pain) that recurred at frequent intervals for some hours. Between these episodes, she was painless but refused to eat or drink. During palpation, a mass was suspected in the right hemiabdomen. The rectal examination was unremarkable, and no bloody diarrhoea was present. Abdominal sonography with a linear transducer revealed an ileocolic intussusception (figure 1). ${ }^{1}$ For hydrostatic reduction, warmed saline was instilled in the rectum. The intussuscepted ileum was smoothly pushed back under ultrasound guidance. Figure 2 shows the situation after hydrostatic reduction, with saline flowing from the cecum through the thickened ileocecal valve into the terminal ileum.

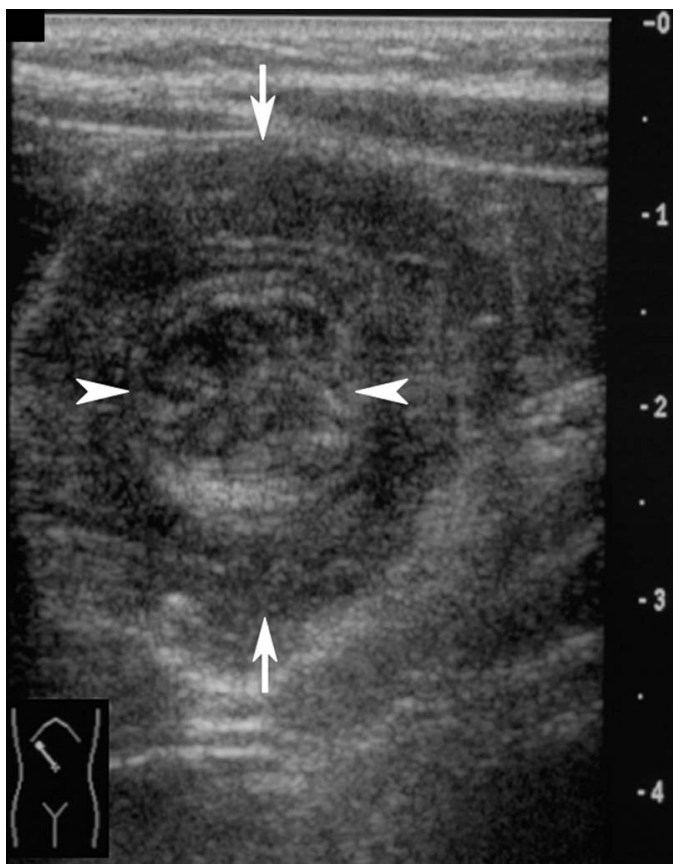

Figure 1 Sonography with a linear transducer showed a typical target sign with the central entering limb (arrowheads) and outer returning limb (arrows) of an ileocolic intussusception.
Intussusception describes the telescoping of a bowel segment into an adjacent segment. Ileocolic intussusception is the most common cause of intestinal obstruction in children between 3 months and 6 years of age, with an incidence of $0.3-4$ per 1000 individuals. $^{2}{ }^{3}$ In this age group, most cases are idiopathic without a pathological lead point, apart from a possible association with hypertrophied lymphoid tissue in the terminal ileum. ${ }^{2}$ Untreated intussusception is often fatal since most cases do not resolve spontaneously. ${ }^{3}$ With a timely diagnosis, many patients can be treated successfully without surgery. This may be performed by air enema or contrast fluid enema under x-ray fluoroscopic control. ${ }^{23}$ A radiation-free alternative is hydrostatic reduction under sonography-guidance. ${ }^{2}$ If such pneumatic or hydrostatic reduction is impossible or contraindicated, then surgery is required. ${ }^{3}$

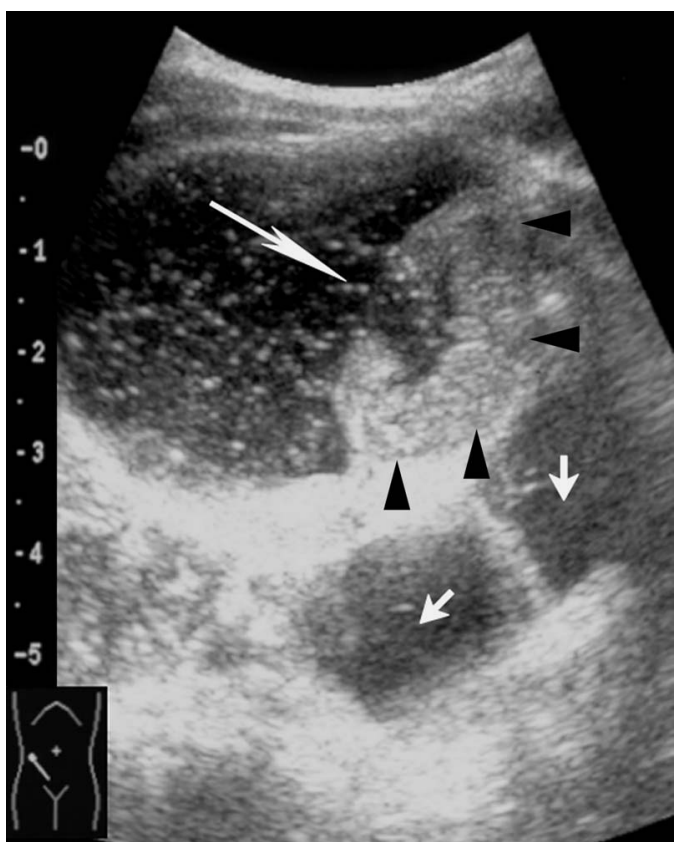

Figure 2 After successful hydrostatic reduction, saline was flowing from the cecum (long arrow) through the thickened ileocecal valve (arrowheads) into the terminal ileum (short arrows). 


\section{BMJ Case Reports}

\section{Learning points}

- Ileocolic intussusception typically presents with intermittent colicky pain.

- lleocolic intussusception can be well diagnosed by sonography.

- A radiation-free treatment is hydrostatic reduction under sonography-guidance.
Competing interests None.

Patient consent Obtained.

\section{REFERENCES}

1. Hryhorczuk AL, Strouse PJ. Validation of US as a first-line diagnostic test for assessment of pediatric ileocolic intussusception. Pediatr Radiol 2009;39:1075-9.

2. Applegate KE. Intussusception in children: evidence-based diagnosis and treatment. Pediatr Radiol 2009;39(Suppl 2):S140-3.

3. Kaiser AD, Applegate KE, Ladd AP. Current success in the treatment of intussusception in children. Surgery 2007;142:469-75.

Copyright 2012 BMJ Publishing Group. All rights reserved. For permission to reuse any of this content visit http://group.bmi.com/group/rights-licensing/permissions.

BMJ Case Report Fellows may re-use this article for personal use and teaching without any further permission.

Please cite this article as follows (you will need to access the article online to obtain the date of publication).

Menke J. lleocolic intussusception and hydrostatic reduction in a 2-year-old girl. BMJ Case Reports 2012;10.1136/bcr-2012-007466, Published XXX

Become a Fellow of BMJ Case Reports today and you can:

- Submit as many cases as you like

- Enjoy fast sympathetic peer review and rapid publication of accepted articles

- Access all the published articles

- Re-use any of the published material for personal use and teaching without further permission

For information on Institutional Fellowships contact consortiasales@bmjgroup.com

Visit casereports.bmj.com for more articles like this and to become a Fellow 